\title{
Highlights of Climate Change Impact on Hydrologic Flows in Five Basins of Ethiopia
}

\author{
Mekin Mohammed \\ Ethiopian Institute of Agricultural Research (EIAR), Mehoni Agricultural Research Center, P.O. Box 71, \\ Ethiopia
}

\begin{abstract}
Climate changes is a global phenomenon exhibited by three prominent signals, that is: (1) global average temperatures are gradually increasing, (2) changes in global rainfall patterns and (3) rising of sea levels. The objective of this paper is review climate change impact on hydrologic flows of five basins of Ethiopia. This study reviewed climate change impact studies in five basins of Ethiopia: Blue Nile, Awash basin, Baro Akobo, Central Rift valley and Tekeze basin. Several studies approved that Ethiopia is vulnerable to climate change since the economy of the country mainly depends on agriculture, which is very sensitive to climate change. Water harvesting technology is very important to minimize climate change impacts.
\end{abstract}

Keywords: Basin, Climate Change, Ethiopia, Hydrologic flow

DOI: $10.7176 /$ JNSR/10-3-04

Publication date: February $29^{\text {th }} 2020$

\section{INTRODUCTION}

\subsection{Background}

Climate changes pose significant economic and environmental risks worldwide. It is a global phenomenon exhibited by three prominent signals, that is: (1) global average temperatures are gradually increasing, (2) changes in global rainfall patterns and (3) rising of sea levels. One of the major impacts of this phenomenon is on local water resource availability, whose impact will be felt by many sectors, including agriculture (Stocker, 2013). Climate change induced by the increase in carbon dioxide and other radioactive trace gases in the atmosphere. This was the focus of scientific investigations due to the fact that climate change has significant implications for the environment, ecosystems, water resources and virtually every aspect of human life (IPCC, 2001).

According to the Intergovernmental Panel on Climate Change (IPCC) Scientific Assessment Report, global average temperature would rise between 1.4 and $5.8^{\circ} \mathrm{C}$ by 2100 with the doubling of the $\mathrm{CO}_{2}$ concentration in the atmosphere. Sea level rise, change in precipitation pattern (up to $\pm 20 \%$ ) and change in other local climate conditions are expected to occur as a consequence of rising global temperature (IPCC-TGICA, 2007). The most important and immediate effects of global warming would be the changes in local and regional water availability, since the climate system is interactive with hydrologic cycle (ARORA and BOER, 1996).

Developing countries, particularly those in Africa are likely to be vulnerable to climate change as recurrent droughts, flood and siltation of water bodies continue to bring misery to millions in Africa (Nawaz et al., 2010). Climate change will increase the number of people living in water stressed regions globally. The impact is worse for the contemporary African population where about $25 \%$ already experience water stress. Considering population increments and water use, it has been estimated that the portion of the African population at risk for water stress and scarcity will increase to $65 \%$ in 2025 . Climate change is, however, expected to aggravate the current stress on water resources availability in Africa (Dile et al., 2013).

The Intergovernmental Panel on Climate Change (IPCC) (2007) suggest that developing countries like Ethiopia will be more vulnerable to climate change because of their economic, climatic and geographic settings. Several studies (example; Ashenafi, 2014; Tekle, 2014; Mekonnen and Disse, 2016) approved that Ethiopia is vulnerable to climate change since the economy of the country mainly depends on agriculture, which is very sensitive to climate change. Both researchers recommend that adoption of water storage practice is very important. On other hand, research conducted on Upper Blue Nile River Basin to assess impacts of climate change on precipitation. From that the positive change of precipitation in future can be a good opportunity for the farmers who are engaged in rain fed agriculture to maximize their agricultural production and to change their livelihoods (Mekonnen and Disse, 2016).

\subsection{Objective}

The main objective is to review different papers about the climate change impact on hydrologic flows of five basins of Ethiopia.

\section{METHODS}

Review different papers which studied about climate change impacts on the hydrologic flows in different parts of 
Ethiopia. This study reviewed climate change impact studies in five basins of Ethiopia: Blue Nile, Awash basin, Baro Akobo, Central Rift valley and Tekeze basin.

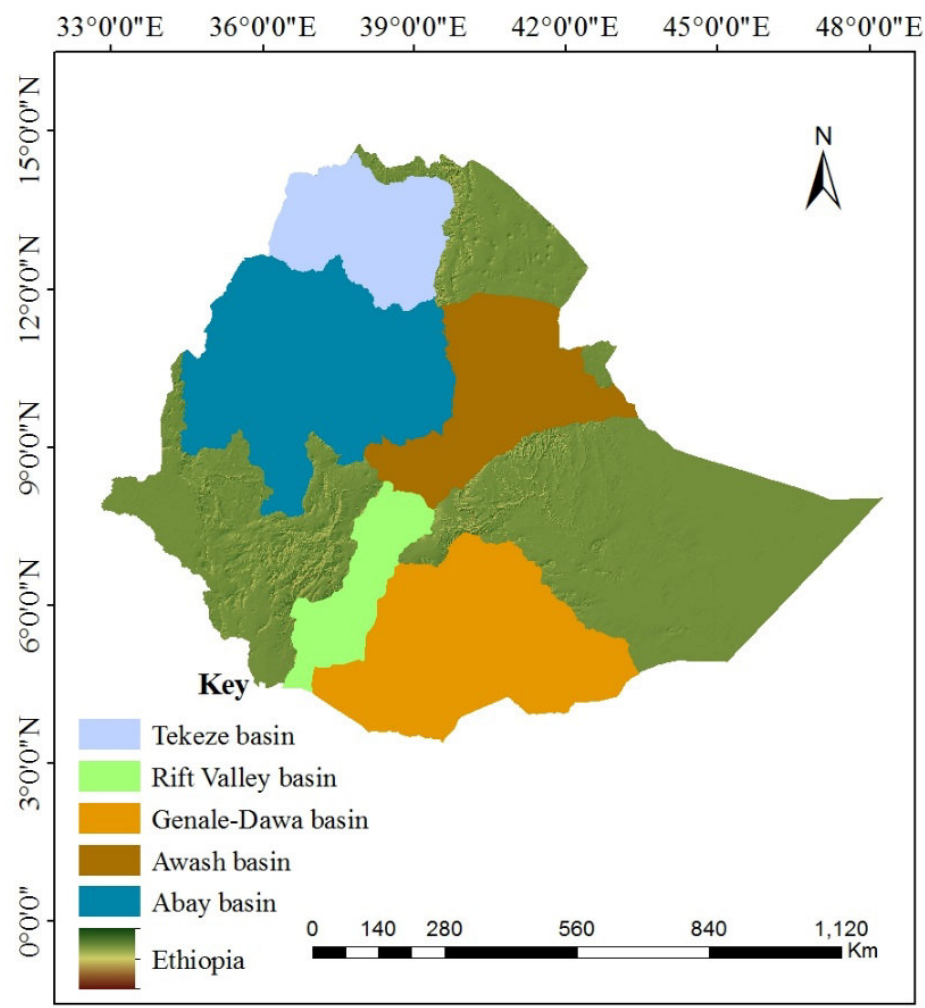

\section{THE IMPACTS OF CLIMATE CHANGE ON HYDROLOGIC FLOWS OF ETHIOPIA}

\subsection{Climate change impacts on hydrologic flow of Blue Nile basin}

The study conducted on Lake Tana basin using different Global Climate Model (GCM) showed that there was a significant decline in mean annual flow for the different time periods. This study added the investigation on the possible impact of climate change on the annual changes in actual ET, soil moisture, surface runoff, and groundwater for the periods of 2046-2065 and 2080-2100. The results indicated that AET increases considerably, on the other hand, soil moisture showed little change (between $0 \%$ and $-2 \%$ decreases). Groundwater flow and surface runoff projected reduced for future periods (Setegn et al., 2011). Other study conducted Lake Tana subbasin to predict the impact of climate change on water resource using different GCM. The study predicts a reduction of annual runoff by $12.6 \%-18.2 \%$ for future periods (Tarekegn and Tadege, 2006). The other study conducted on this catchment to investigate about impact of climate change on hydrological behavior. The study showed that in summer season, (June -September) in which the basin receives above $70 \%$ of the rainfall amount, the precipitation increased by about 2.6 and 5.7\% for ECHAM and IPSL, respectively. At the end of the $21 \mathrm{st}$ century ECHAM and IPSL project again an increase in precipitation by about 3.5 and $5.8 \%$ respectively. And this study summarizes, the precipitation changes by small amount or show a significant decrease in some of the summer months like June when the basin receives more than $70 \%$ of the total precipitation. The significant rise in winter precipitation for both future periods could indicate that there would be also seasonal shift in precipitation due to the changing climate. And this study added potential evapotranspiration is expected to increase for future periods. At the end of the 21 st century potential evapotranspiration is expected to increase in all months of the year. The minimum and maximum increase in potential evapotranspiration is $3.9 \%$ and $15 \%$ in January and December respectively (Enyew et al., 2014).

The other study conducted on the Upper Blue Nile River Basin (UBNRB) showed that there might be an increase in mean annual precipitation for three time windows $(2030 \mathrm{~s}, 2050 \mathrm{~s}$ and $2080 \mathrm{~s})$ under all scenarios in the range of $2.1 \%$ to $43.8 \%$ under the $\mathrm{A} 2 \mathrm{a}$ and RCP8.5 scenarios respectively. At $2080 \mathrm{~s}$, the maximum relative change of mean annual precipitation is expected to be $43.8 \%$ under RCP8.5 scenario, while the minimum relative change of mean annual precipitation to be $2.1 \%$ at 2050s (Mekonnen and Desse, 2016).

The study conducted on Megech catchment of Blue Nile showed that the mean monthly precipitation shows both increasing and decreasing trend for both A1B and B1 scenario for future period (2015-2050). It is likely to be increased in the range of $+6.7 \%$ to $+34.5 \%$ and $+11.0 \%$ to $+38.89 \%$ while it is projected to be decreased in the range between $-1.14 \%$ to $-31.88 \%$ and $-1.6 \%$ to $-36.42 \%$ for A1B and B1 scenarios respectively (Abebe and 
Kebede, 2017).

\section{2. climate change impacts on hydrologic flow of Awash basin}

The study conducted on Lake Haik of Awash basin showed that water level fluctuation is higher. The study approved that the water level became decrease through time (Tadess et al., 2011). Workiye (2009) observed that the water level of Lake Haiq was appreciably lower at the time of their visit in January 1969 than in May 1938 (Tadese et al., 2011) According to MoWR (2000) water storage capacity of Lake Haiq was $1034 \times 10^{6} \mathrm{~m}^{3}$ but in 2007 the storage capacity reduced to $988.7 \times 10^{6} \mathrm{~m}^{3}$ Molla et al., 2007). Other study conducted by Abi (2016) showed that the annual average flow volume showed an increasing trend and the maximum increment was reached up to an average of $14.90 \%$ from 2017 to 2100 .

\subsection{Climate change impacts on hydrologic flow of Rift valley basins}

The impact of sedimentation and climate variability on the hydrological status was investigated by Belete (2013). The author showed correlation between the water level variability and the occurrences of the El Niño-Southern Oscillation (ENSO) phenomenon, and approved that the water level of Lake Hawassa became rise due to climate variability impacts.

The other study conducted at Bilate watershed in the Ethiopian Rift valley basin using GCM and SWAT out puts, the results showed that average total seasonal flow shows decreasing pattern in month of March to September for A2a scenario but for B2a scenario it is almost constant. But in months of October to February there might be an increasing pattern of average total seasonal flow in both scenarios (2020s, 2040s and 2070s) (Tekle, 2014)

\subsection{Climate change impacts on hydrologic flow of Genale-Dawa basin}

The research conducted on Weyb watershed in Genale-Dawa basin using GCM and SWAT model showed that, precipitation will increase in the dry season and decrease in the wet season (the main rainy season) for both A2a and B2a scenarios. The overall increase in mean annual precipitation for both A2a and B2a scenarios (Shawul et al., 2016). In all future time series, for the months of November and December, the projected rainfall amounts could increase with large magnitude compared with the baseline period, for both A2a and B2a scenarios. But for the rainiest months of the year, August and September, the model shows a decrease in each future time series for both A2a and B2a scenarios. For the months of January, February, March, and April, the projected rainfall amount increased from the baseline period except for January and February 2080s which presented a decrease for both A2a and B2a scenarios. On the other hand, for the months of May, June, July, and October, the projected rainfall amount in all future time horizons shows a negligible change from the baseline period for both A2a and B2a scenarios. Future mean annual precipitation with a range of $909.01 \mathrm{~mm}$ to $1163.47 \mathrm{~mm}$ for years 2040 and 2061, respectively, for A2a scenario, and $954.85 \mathrm{~mm}$ to $1136.57 \mathrm{~mm}$ for years 2042 and 2090, respectively, for B2a scenario. It shows substantial variability of total average annual precipitation from year to year (Shawul et al., 2016).

\subsection{Climate change impacts on hydrologic flow of Tekeze basin}

The mean annual precipitation in the future increases over Tekeze basin. The change in mean annual precipitations varies from +32 to $+40 \%$ for mid rang RCP4.5 and high level RCP8.5 scenario over all future time periods. In all future time periods, Kiremt season (June-September) precipitation showed an increasing trend and varies from +21 to $+48 \%$, but in Belg season (February-May) precipitation amount decreased and varies from - 15 to - 52\% under both RCP4.5 and RCP8.5 climate scenarios. The Bega season (October-January) showed a mixed trend where precipitation decreased up to $-23 \%$ in 2050 s under RCP 4.5 and $-39.5 \%$ in 2020 s (2011-2040) for RCP8.5 scenarios. On the other hand, precipitation increases from +5.7 to $+50 \%$ under both RCP4.5 and RCP8.5 climate scenarios (Fantaw et al., 2018).

In Tekeze basin, climate scenarios produced moderate increase in mean annual streamflow which is due to projected increased in precipitation. However, RCP8.5 climate scenario in 2080s (2070-2100) showed a decrease in streamflow due to high increased in projected temperature that leads to increase in evapotranspiration than increased in precipitation. The mean annual streamflow varies from 39 to $50 \%$ in RCP4.5 and 10 to $23 \%$ in RCP8.5 climate scenarios but decreased in 2080s (2070-2100) up to $23 \%$ under RCP8.5 climate scenarios (Fantaw et al., 2018).

\section{Summary}

Several studies conducted in Ethiopia strongly suggest that, water resource of the country respond to global warming in ways that will negatively affect the water availability and water supplies. The studies conducted in Upper Blue Nile basin, Awash Basin, Rift Valley basin, Genale-Dawa basin and Tekeze basin of Ethiopia showed that, the climate change has the sever impacts on hydrologic flows of the country. Due to erratic rainfall 
distribution (because of climate change); declining the surface water, increased evapotranspiration, lower flows and river became decline in one season and highly increased in another season on the country. The decrease in the runoff volume will lead to the decrease in the inflow to the reservoirs consequently; longer period might be required to fill the reservoir (Best example is like koka reservoir). As result of the rise in temperature the rate of evaporation from the reservoir open water surface may increase and this may create the reservoir to fail to supply at least the required amount of demand because of its depletion or decrease in its storage volume and/or water level. On the other hand, climate change affects water resource through increasing runoff that leads to sedimentation and flooding. In addition, climate change affects hydrologic flow of Ethiopia through unhealthy distribution of rainfall that leads to drought in one season and flooding on another season. Water harvesting technology is very important to minimize climate change impacts.

\section{Reference}

Abebe E., and Kebede A,.2017. Assessment of climate change impacts on the water resource of Megech River catchment, Abbay Basin, Ethiopia. Journal of Modern Hydrology, 2017, 7, 141-152.

Abi D.2016. Impact of climate change on hydrological behavior of ankara watershed, northern awash basin, Ethiopia. MSc thesis. Unpublished.

ARORA and BOER. 1996. The effect of simulated climate change on the hydrology of major river basins. Water resource Res.Submitted.

Ashenafi, A. A. 2014. Modeling hydrological responses to changes in land cover and climate in Geba river Basin, Northern Ethiopia (Doctoral dissertation, Freie Universität Berlin).

Belete, M.D., 2013. The impact of sedimentation and climate variability on the hydrological status of Lake Hawassa, South Ethiopia (Doctoral dissertation, Universitäts-und Landesbibliothek Bonn).

Dile, Y.T., Berndtsson, R. and Setegn, S.G., 2013. Hydrological response to climate change for gilgel abay river, in the lake tana basin-upper Blue Nile basin of Ethiopia. PloS one, 8(10), p. e79296.

Fentaw, F., Hailu, D., Nigussie, A. and Melesse, A.M., 2018. Climate Change Impact on the Hydrology of Tekeze Basin, Ethiopia: Projection of Rainfall-Runoff for Future Water Resources Planning. Water Conservation Science and Engineering: 1-12.

IPCC. 2001. The Scientific Basis, Technical Summary of the Working group I. [Housghton,J.t.,Y. Ding.D.J. Griggs,M.Noguer, P.J. Vander Linden, X. Dani K. Maskell, and C.A. Jhonsouleds]. Combridge University press, Combridge, United Kingdom and New yourk,NY, USA, 94pp.

IPCC-TGICA. 2007: General Guidelines on Use of Scenario Data for Climate Impact and Adaptation Assessment.Version 2. Prepared by T.R.Carter on behalf of the IPCC on Climate Change, Task Group on Data and Scenario Support for Impact and Climate Assessment, $66 \mathrm{pp}$.

Kim, U. and Kaluarachchi, J.J., 2009. Climate Change Impacts on Water Resources in the Upper Blue Nile River Basin, Ethiopia 1. JAWRA Journal of the American Water Resources Association, 45(6), pp.1361-1378.

Mekonnen, D.F. and Disse, M., 2016. Analyzing the future climate change of Upper Blue Nile River Basin (UBNRB) using statistical down scaling techniques. Hydrology and Earth System Sciences Discuss.

Molla Demlie, Tena Alamerew, Ayenew, and Stefan, W. 2007. Comprehensive hydrological and hydro geological study of topographically closed Lakes in highland Ethiopia: The case of Haiq and Ardibo. Journal of Hydrology, 339(1), 145-158.

MoWR. 2000. Lake Hayk bathymetric survey report. Addis Abeba, Ethiopia: Ministry of Water Resource.

Setegn, S.G., Rayner, D., Melesse, A.M., Dargahi, B. and Srinivasan, R., 2011. Impact of climate change on the hydroclimatology of Lake Tana Basin, Ethiopia. Water Resources Research, 47(4).

Shawul, A.A., Alamirew, T., Melesse, A.M. and Chakma, S. 2016. Climate change impact on the hydrology of Weyb River watershed, Bale mountainous area, Ethiopia. In Landscape Dynamics, Soils and Hydrological Processes in Varied Climates: 587-613. Springer, Cham.

Stocker, T. ed., 2013. Climate change 2013: the physical science basis: Working Group I contribution to the Fifth assessment report of the Intergovernmental Panel on Climate Change. Cambridge University Press.

Tadesse Fetahi, Seyoum Mengistu, and Michael, S. 2011. Zooplankton community structure and ecology of the tropical-highland Lake Haiq, Ethiopia. Journal Limonologica, 41(1), 389-397.

Tarekegn. D \& Tadege.A. 2005; Assessing the impact of climate change on the water resource of Lake Tana sub -basin using WATBAL model, Ethiopia.

Tekle, A. 2014. Assessment of climate change impact on water availability of Bilate watershed, Ethiopian Rift Valley Basin. In AFRICON, 2015 (pp. 1-5). IEEE.

Workiye Worie. 2009. Some Aspects of the Biology of nile tilapia, oreochromis niloticus 1. 1758 (pisces: cichlidae) in Lake Hayq, Ethiopia. M.Sc thesis, Addis Ababa University. 